\title{
A Widely Distributed Lineage of Xanthomonas oryzae pv. oryzae in India May Have Come from Native Wild Rice
}

J. Yashitola, Centre for Cellular and Molecular Biology, Uppal Road, Hyderabad-500007, A. P., India; A. P. K. Reddy, Directorate of Rice Research, Indian Council of Agricultural Research, Rajendra Nagar, Hyderabad-500030, A. P., India; and Ramesh V. Sonti, Centre for Cellular and Molecular Biology, Uppal Road, Hyderabad-500007, A. P., India

\begin{abstract}
Yashitola, J., Reddy, A. P. K., and Sonti, R. V. 2000. A widely distributed lineage of Xanthomonas oryzae pv. oryzae in India may have come from native wild rice. Plant Dis. 84:465-469.

Xanthomonas oryzae pv. oryzae causes bacterial leaf blight, a serious disease of rice. We have collected leaf blight-affected samples from wild rice (Oryza nivara) plants growing naturally at 22 locations in five revenue districts (Nalgonda, Ranga Reddy, Medak, Nizamabad, and Adilabad) in the Telangana Region of Andhra Pradesh, India. Pathotype analysis on a set of differential rice cultivars and DNA fingerprinting with two multilocus restriction fragment length polymorphism probes indicated that the $X$. oryzae pv. oryzae strains from the $O$. nivara plants belonged to a pathotype and lineage previously widely distributed among cultivated rice in India. This suggests that the lineage may be native to wild rice and may have been transferred subsequently to cultivated rice plants.
\end{abstract}

Additional keywords: bacterial blight of rice, genetic diversity, population structure

Bacterial leaf blight, caused by Xanthomonas oryzae pv. oryzae (15), is a serious disease of rice. The disease occurs globally from Asia to Africa to the Americas (10) with varying degrees of virulence. Earlier studies on the population structure of $X$. oryzae pv. oryzae, using differential rice cultivars, revealed that pathotype $1 \mathrm{~b}$ is widely distributed in India (12,13). A study of the genetic diversity of $X$. oryzae. pv. oryzae in India, using DNA fingerprinting methods as well as pathotyping on differential rice cultivars (19), indicated that one lineage of this pathogen belonging to pathotype $1 \mathrm{~b}$ is widely distributed in India.

Bacterial leaf blight emerged as a serious disease of rice in India after the introduction of semidwarf, high yield, susceptible rice cultivars. Srivastava (14), suggested the possibility that the pathogen was introduced into India in the seeds of these cultivars. To address this issue, the wild rice habitats of the Deccan Plateau were surveyed for the presence of the disease. The genetic make up and pathogenicity of $X$. oryzae pv. oryzae strains from wild rice (Oryza nivara Sharma \& Shastry) plants (17) were studied and found to be related to those obtained from cultivated rice plants.

Accepted for publication 10 December 1999.

Corresponding author: R. V. Sonti

E-mail: sonti@ccmb.ap.nic.in

Publication no. D-2000-0125-02R

(C) 2000 The American Phytopathological Society

\section{MATERIALS AND METHODS}

Bacterial strain collection. Native wild rice growing in the Deccan Plateau region of India was surveyed for the occurrence of bacterial blight. Wild rice grows naturally in marshy areas and small pools during the monsoon season. The plants are characterized by weedy habits and conspicuous long awns (Fig. 1). The surveyed districts are shown in Figure 2. Strains, collection sites, and year of collection are listed in Table 1 .

Isolation of bacteria. Wild rice leaves showing bacterial blight symptoms were collected, surface-sterilized with $2 \%$ sodium hypochlorite for $1 \mathrm{~min}$, and washed four times with sterile double-distilled water. Sterilized leaves were cut into $1-\mathrm{cm}$ pieces and plated on peptone sucrose agar (PSA) medium $(4,16)$. $X$. oryzae pv. oryzae cells oozed from vascular tissues and formed colonies on PSA plates. Cells were isolated by single-colony transfers and stored at $-70^{\circ} \mathrm{C}$ in $20 \%$ glycerol. Alternatively, infected leaves were surface-sterilized with $2 \%$ sodium hypochlorite for $1 \mathrm{~min}$, washed twice with sterile distilled water, cut into $0.5-\mathrm{cm}$ pieces, and placed in $10 \mathrm{ml}$ of sterile distilled water. The cells were allowed to ooze from leaves into sterile water and streaked for single-colony isolation on PSA plates prior to long-term storage at $-70^{\circ} \mathrm{C}$ in $20 \%$ glycerol.

Isolation of DNA and Southern hybridization. Genomic DNA was isolated according to the procedure described by Leach et al (9). For hybridization with avrXa10, DNA was digested to completion with the enzyme BamHI (New England Biolabs, Beverly, MA). For hybridization with IS1112, DNA was digested with EcoRI (New Eng- land Biolabs). Separation of digested DNA fragments and Southern blot hybridization with $\alpha^{32} \mathrm{PdATP}$-labeled probes were done as described previously (19). BstEII-digested $\lambda$ DNA was included in all gels as a marker.

Probes. Two repeat elements from the $X$. oryzae pv. oryzae genome were used as probes for Southern blot hybridization: an avirulence gene probe $a v r X a 10$ (5) and an insertion sequence IS1112 (9). These probes have demonstrated genetic diversity in the past within $X$. oryzae pv. oryzae strains in the Philippines, India, and several locations in Asia $(1,8,11,19)$.

Data analysis. Bands revealed by Southern blot analysis were scored as 1 or 0 , for presence or absence of a particular band, respectively. The data were analyzed using the Dice coefficient option in the program WINDIST (18) to generate distance ma-

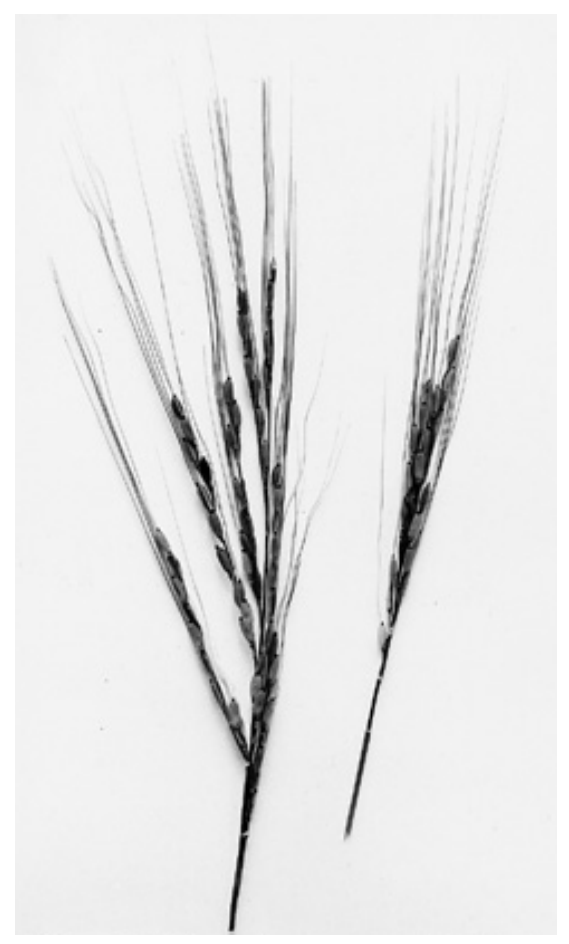

Fig. 1. Panicles of wild rice (Oryza nivara) plants collected from the Deccan Plateau Region of India. Long red awns and grain shattering are characteristic features of this species. 
trices. A triangular matrix was obtained that was used to construct a dendrogram using the NEIGHBOR program in PHYLIP (phylogeny inference software package; Department of Genetics, University of Washington, Seattle) using the UPGMA (unweighted pair group method of averages) option (3). To test the robustness of the dendrogram, bootstrap analysis was carried out using the WinBoot program (18) with 2,000 iterations. The bootstrap values are expressed as a percentage of the 2,000 iterations.

Pathotyping. X. oryzae pv. oryzae strains collected from wild rice were categorized on differential rice cvs. BJ1, DV85, IET8585, CempoSelak, IR20, and TN-1. The seeds of these cultivars were obtained from the Directorate of Rice Research (Indian Council of Agricultural Research, Rajendra Nagar, Hyderabad, India). The plants were grown in plastic pots $(17 \mathrm{~cm}$ diameter $\times 15 \mathrm{~cm}$ height) under flooded conditions in the greenhouse on soil obtained from the rice farm of the Directorate of Rice Research. Pots were filled with a mixture of soil and farmyard manure at a ratio of 3:1. N-P-K was supplied to the plants at a rate of 100$75-75 \mathrm{~kg} / \mathrm{ha}$ as the basal dose, in the form of urea, superphosphate, and muriate of potash. Fifteen-day-old rice seedlings were transplanted to the pots. Five seedlings were planted in each pot, with care taken to leave equal spacing between seedlings. Pots were irrigated every day. Plants were top-dressed with urea at a rate of $50 \mathrm{~kg} / \mathrm{ha}$ at the tillering stage. Adequate plant protection measures were taken to ensure healthy, vigorous plant growth. Forty-day-old plants were clipinoculated (7) with scissors dipped in bacterial suspensions of $10^{9}$ cells per ml. An average of 20 leaves per pot were inoculated for each strain-cultivar combination.

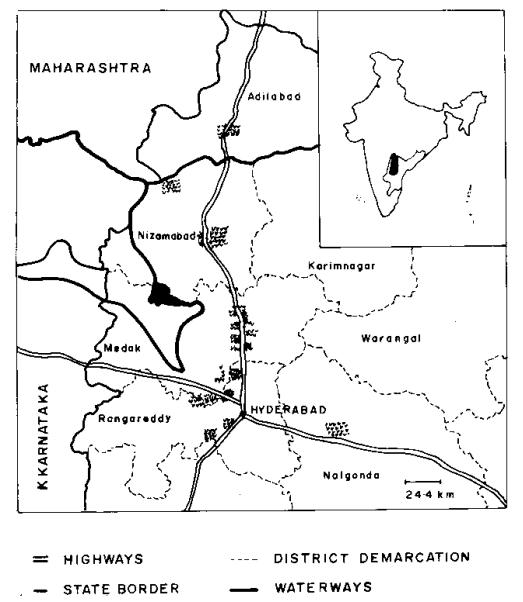

Fig. 2. Collection sites of Xanthomonas oryzae pv. oryzae strains from wild rice. Squiggly lines indicate wild rice pools from which $X$. oryzae pv. oryzae strains were isolated. Inset contains a map of India with the state of Andhra Pradesh outlined. The shaded area represents the region within this state that was investigated.
Table 1. Xanthomonas oryzae strains isolated from wild rice and cultivated rice in India

\begin{tabular}{|c|c|c|}
\hline Strain $^{a}$ & Location $^{b}$ & Year \\
\hline BXO1 & Chinsuria, West Bengal & 1992 \\
\hline $\mathrm{BXO} 4$ & Kapurthala, Punjab & 1992 \\
\hline BXO5 & Ferozpur, Punjab & 1992 \\
\hline BXO454 & Warangal, Andhra Pradesh & 1996 \\
\hline BXO471 & Rajendra Nagar, Ranga Reddy District & 1996 \\
\hline BXO452 & Rajendra Nagar, Ranga Reddy District & 1996 \\
\hline BXO507 & Rajendra Nagar, Ranga Reddy District & 1996 \\
\hline BXO512 & Gachibowli, Ranga Reddy District & 1996 \\
\hline BXO521 & Madhavpuram, Nalgonda District & 1996 \\
\hline BXO525 & Miyapur, Ranga Reddy District & 1996 \\
\hline BXO532 & Near Rajendra Nagar, Ranga Reddy District & 1996 \\
\hline BXO554 & Ugma Cheruvu, Ranga Reddy District & 1997 \\
\hline BXO555 & Nanakrampet, Ranga Reddy District & 1997 \\
\hline BXO556 & Near Nanakrampet, Ranga Reddy District & 1997 \\
\hline BXO557 & Gowlidoddi, Ranga Reddy District & 1997 \\
\hline BXO558 & Masaipet, Medak District & 1997 \\
\hline BXO559 & Near Masaipet, Medak District & 1997 \\
\hline BXO562 & Near Masaipet, Medak District & 1997 \\
\hline BXO563 & Near Masaipet, Medak District & 1997 \\
\hline BXO566 & Ramantapur, Medak District & 1997 \\
\hline BXO568 & Near Ramantapur, Medak District & 1997 \\
\hline BXO571 & Tufran, Medak District & 1997 \\
\hline BXO574 & Near Tufran, Medak District & 1997 \\
\hline BXO578 & Near Tufran, Medak District & 1997 \\
\hline BXO582 & Sugalpalli, Nizamabad District & 1997 \\
\hline BXO589 & Nirmal, Adilabad District & 1997 \\
\hline BXO590 & Basra, Nizamabad District & 1997 \\
\hline BXOR1 & Rajendranagar, Ranga Reddy District & 1996 \\
\hline
\end{tabular}

a All strains belong to $X$. oryzae pv. oryzae, except BXOR1; BXOR1 is a X. oryzae pv. oryzicola strain. All $X$. oryzae pv. oryzae strains, except BXO 1, 4, 5, 454, and 471, were obtained from Oryza nivara plants. BXO 1, 4, 5, 454, and 471 were isolated from cultivated rice (19).

${ }^{b}$ The 22 collection sites are separated from each other by distances that range from a minimum of 1 $\mathrm{km}$ to a maximum of $445 \mathrm{~km}$.

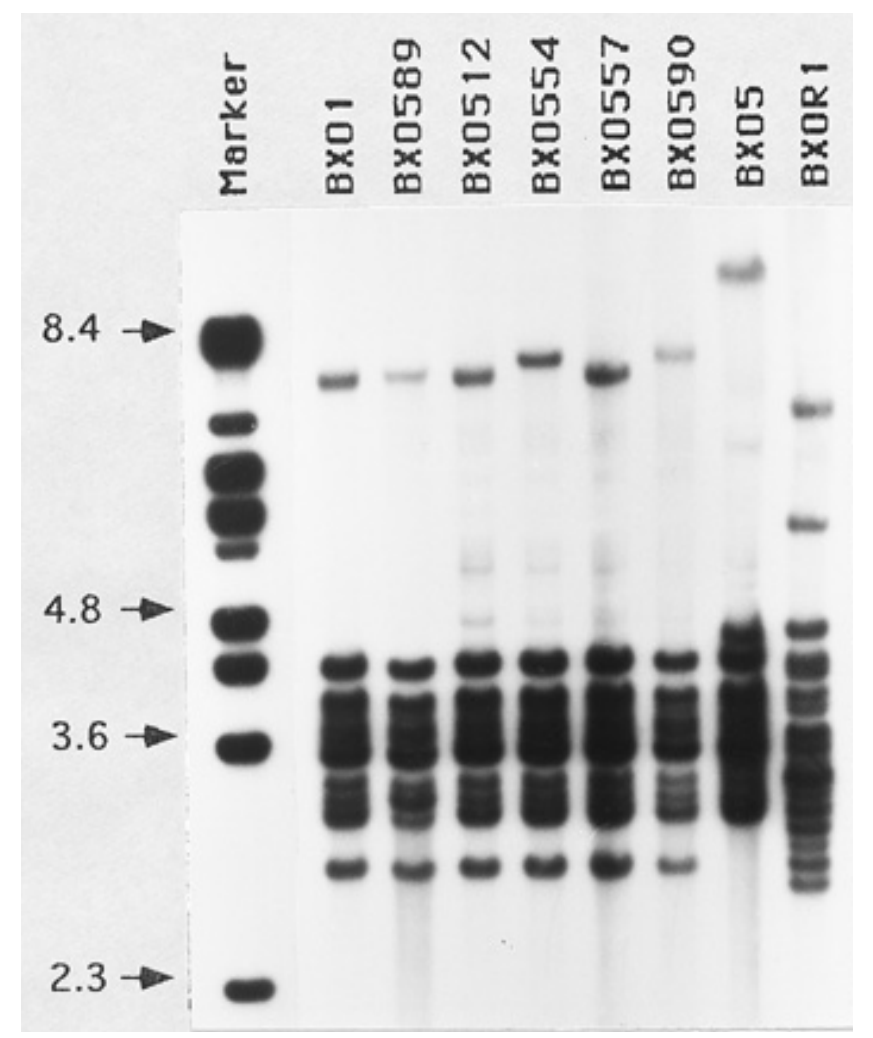

Fig. 3. Restriction fragment length polymorphism analysis of wild rice isolates of Xanthomonas oryzae pv. oryzae with the avrXa10 probe. BXO1, the type strain for pathotype $1 \mathrm{~b}$, and $\mathrm{BXO5}$, a non-BXO1 lineage strain, were added for comparison. BXOR1, a Xanthomonas oryzae pv. oryzicola strain, was added as an outgroup. Each strain was analyzed at least twice, and the same haplotype was obtained each time. Marker, BstEII-digested $\lambda$ DNA. 
Disease scores were evaluated 15 days after inoculation based on a 0 to 9 scale $(6,7): 0=$ no visible lesions; $1=$ lesions restricted to 0.5 to $1.0 \mathrm{~mm} ; 3=$ lesions elongated but less than one-quarter of the leaf blade; $5=$ lesions extend to half the leaf blade; $7=$ lesions extend three-quarters of the blade from tip to base; $9=1$ esions completely destroy leaf blade and sheath. A disease score of less than 4 was rated as a resistant reaction; 4 to 5 was moderately susceptible; greater than 5 was considered susceptible $(6,7)$. Appropriate statistical methods were used to analyze the data set. Previous studies $(12,13,19)$ indicated that an $X$. oryzae pv. oryzae lineage widely distributed on cultivated rice in India is incompatible with rice cvs. BJ1 and DV85.

\section{RESULTS}

Haplotype variation detected with restriction fragment length polymorphism probes. Genomic DNA isolated from 22 strains was digested to completion with BamHI, and Southern blot hybridization was carried out with the $a v r X a 10$ probe. Two haplotypes were observed. Nineteen of the strains (BXO 452, 507, 512, 521, 525, 532, 555, 557, 558, 559, 562, 563, 566, $568,571,574,578,582$, and 589) were a haplotype (Fig. 3) that is identical to BXO1, the type strain of a widely distributed lineage of $X$. oryzae pv. oryzae obtained from cultivated rice in India (19). BXO 554, 556, and 590 (Fig. 3) are a different haplotype with a band at $\approx 12 \mathrm{~kb}$, whereas BXO1 and others had a band at $\approx 11 \mathrm{~kb}$. BXO5 is a non-BXO1 lineage strain isolated from cultivated rice and characterized previously (19). BXO5 was added for comparison, and as observed earlier (19), the haplotype of this strain is distinctly different from that of the BXO1 lineage strains. The BXOR1 strain belongs to $X$. oryzae pv. oryzicola, a pathovar that causes bacterial leaf streak of rice. As expected for an outgroup strain, the BXOR1 haplotype is very different from that of the $X$. oryzae pv. oryzae strains.

Three haplotypes were observed with the IS1112 probe (Fig. 4). A majority of the strains analyzed had a haplotype that, again, was identical to BXO1 (BXO 452, 507, 521, 525, 554, 555, 556, 558, 559, 562, 563, 566, 568, 571, 574, 578, 582, 589, and 590). Two strains, BXO 512 and 532, had a related but distinct haplotype that was not observed in any of the $X$. oryzae pv. oryzae strains from cultivated rice analyzed earlier (19). Strain BXO557 had a haplotype that was identical to $\mathrm{BXO} 4$, a strain obtained from cultivated rice in the Punjab Province in North India (19). As expected, the BXO5 and BXOR1 strains have distinctly different haplotypes.

Phylogenetic analysis. Cluster analysis of the strains was done using the WINDIST and PHYLIP programs. The restriction fragment length polymorphism data for both probes were combined, and difference coef- ficients were obtained. A dendrogram was constructed (Fig. 5) that showed a cluster of four closely related ( $92 \%$ similarity) haplotypes for the wild rice strains. The bootstrap value for this cluster is $100 \%$, indicating that it is a very strong cluster. Bootstrap values for the internal branches within this cluster were low, indicating that although the strains belong to one lineage relationships within this lineage are not clear. Felsenstein (2) suggested that only clusters having a bootstrap value $>95 \%$ should be considered robust. The non-BXO1 lineage strain, BXO5, clusters at the $63 \%$ similarity level with the wild rice $X$. oryzae pv. oryzae strains. As expected for an outgroup strain, BXOR1 clusters with the $X$. oryzae pv. oryzae strains at only the $30 \%$ similarity level.

Pathotyping of $X$. oryzae pv. oryzae strains from wild rice. Fifteen strains used in DNA fingerprinting analysis were inoculated on differential rice cvs. DV85, BJ1, IET8585, CempoSelak, and IR20.

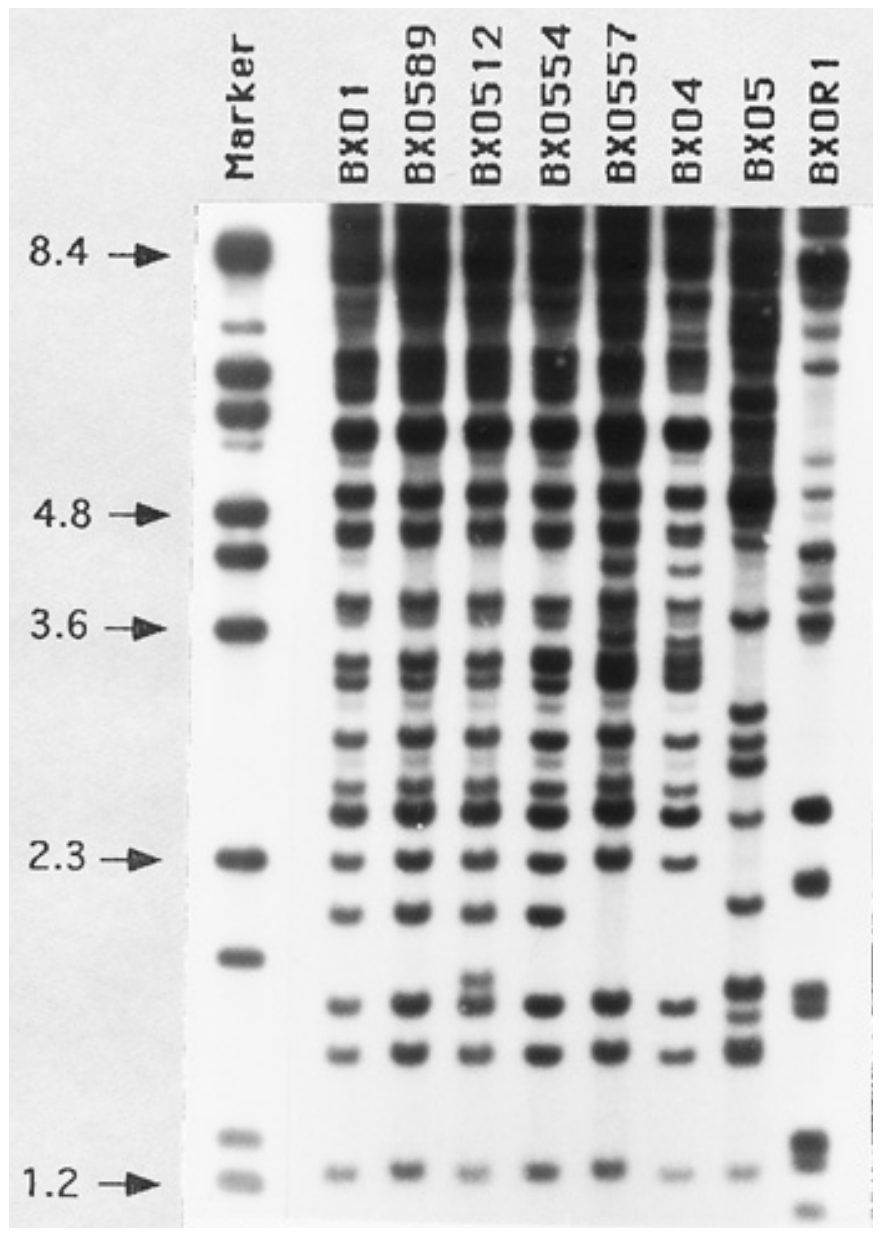

Fig. 4. Restriction fragment length polymorphism analysis of wild rice isolates of Xanthomonas oryzae pv. oryzae with the IS1112 probe. The BXO1, BXO4, and BXO5 strains were added for comparison, and BXOR1 was added as an outgroup strain. Each strain was analyzed at least twice, and the same haplotype was obtained each time. Marker, BstEII-digested $\lambda$ DNA.

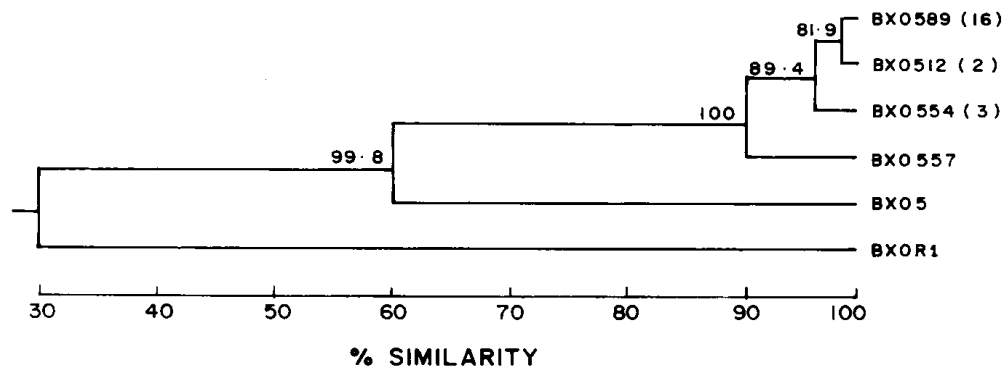

Fig. 5. A dendrogram of Xanthomonas oryzae pv. oryzae strains isolated from wild rice plants. The dendrogram was constructed using the UPGMA option of PHYLIP on the basis of restriction fragment length polymorphism data obtained with avrXa10 and IS 1112 probes. Numbers at the internal branches indicate bootstrap values for clusters to the right of each number. 
IRBB21, an isogenic rice line carrying the $X a-21$ gene was included in the pathotype analysis. Thirteen strains (BXO 452, 507, 556, 559, 562, 563, 568, 571, 574, 578, 582, 586 , and 589) showed similar reactions on all rice differentials (Table 2). These strains did not cause disease on BJ1, DV85, and IET 8585 but did cause disease on IR20 and CempoSelak and, therefore, were similar to the previously described pathotype $1 \mathrm{~b}$ $(12,13,19)$. Two strains (BXO 554 and 590) isolated from separate locations showed a slightly different reaction type on these cultivars. The two strains were not able to cause disease on BJ1, DV85, IET8585, and IR20. Such strains have been previously classified as pathotype 1a $(12,13)$. Therefore, the majority of the strains analyzed in this study are classified as pathotype $1 \mathrm{~b}$. None of the 14 strains analyzed caused disease on IRBB21, however, suggesting that $X a-21$ could be useful against both pathotypes 1a and 1b. Strains BXO 454 and 471 , isolated from cultivated rice and categorized as pathotype $1 \mathrm{~b}$ in a previous study (19), were included as controls (Table 2).

\section{DISCUSSION}

Bacterial leaf blight emerged as a major production constraint for rice cultivation in India with the introduction of semidwarf rice cultivars during the 1960s (14). It has been suggested that the disease was introduced into India in seeds of semidwarf cultivars. DNA fingerprinting and pathotype analysis on $X$. oryzae pv. oryzae strains collected from naturally infected leaves of wild rice plants growing in their native habitat was performed. Many of the locations sampled were several kilometers from cultivated rice plants, yet the bacteria isolated from wild rice plants belonged to a lineage that is widely distributed within cultivated rice plants in India. This suggests that this lineage of $X$. oryzae pv. oryzae may be native to wild rice and may have moved to susceptible cultivars introduced to these areas since the 1960s.

An alternative scenario in which the BXO1 lineage strains may have moved to wild rice from cultivated plants cannot be ruled out. We consider this to be less likely, however, because of the spatial separation between wild and cultivated rice plants at many of the locations sampled. Also, due to the prevailing agro-climatic conditions, bacterial leaf blight has not been a serious disease of cultivated rice in the study area. Under the circumstances, such widespread dissemination of the BXO1 lineage would not be expected to have progressed from cultivated to wild rice plants.

\section{LITERATURE CITED}

1. Adhikari, T. B., Vera Cruz, C. M., Zhang, Q. Nelson, R. J., Skinner, D. Z., Mew, T. W., and Leach, J. E. 1995. Genetic diversity of Xanthomonas oryzae pv. oryzae in Asia. Appl. Environ. Microbiol. 61:966-971.

2. Felsenstein, J. 1985. Confidence limits on phylogenies: An approach using the bootstrap. Evolution 39:783-791.

3. Felsenstein, J. 1989. PHYLIP-Phylogeny inference package (version 3.41). Cladistics 5: 164-166.

4. Hayward, A. C. 1960. A method for characterizing Pseudomonas solanacearum. Nature (Lond.) 186:405-406.

5. Hopkins, C. M., White, F. F., Choi, S. H., Guo, A., and Leach, J. E. 1992. Identification of a family of avirulence genes from Xanthomonas oryzae pv. oryzae. Mol. Plant-Microbe

Table 2. Virulence of Xanthomonas oryzae pv. oryzae strains isolated from wild rice species on differential rice cultivars ${ }^{\mathrm{a}}$

\begin{tabular}{|c|c|c|c|c|c|c|c|c|c|}
\hline \multirow{2}{*}{\multicolumn{2}{|c|}{$\begin{array}{l}\begin{array}{l}\text { Bacterial } \\
\text { strain }^{\mathbf{b}}\end{array} \\
\end{array}$}} & \multicolumn{7}{|c|}{ Rice cultivar ${ }^{\mathrm{c}}$} & \multirow[b]{2}{*}{ Mean } \\
\hline & & IRBB21 & DV85 & BJ1 & IET8585 & CempoSelak & IR20 & TN-1 & \\
\hline \multirow[t]{2}{*}{$\mathrm{BXO} 452$} & $(\mathrm{O})$ & $\mathrm{R}(2.0)$ & $\mathrm{R}(3.5)$ & $\mathrm{R}(3.5)$ & $\mathrm{R}(2.5)$ & S (6.5) & S (6.0) & $\mathrm{S}(8.5)$ & 4.6 \\
\hline & $(\mathrm{T})$ & 1.4 & 1.9 & 1.9 & 1.6 & 2.5 & 2.4 & 2.9 & 2.1 \\
\hline \multirow[t]{2}{*}{ BXO507 } & $(\mathrm{O})$ & R (3.0) & R (3.5) & $\mathrm{R}(2.5)$ & R (3.0) & $S(7.5)$ & S (7.0) & S (8.0) & 4.9 \\
\hline & $(\mathrm{T})$ & 1.7 & 1.8 & 1.5 & 1.7 & 2.7 & 2.6 & 2.8 & 2.1 \\
\hline \multirow[t]{2}{*}{ BXO554 } & (O) & R (3.0) & R (3.0) & $\mathrm{R}(3.0)$ & R (3.0) & R (4.0) & $\mathrm{R}(3.0)$ & S (7.0) & 3.7 \\
\hline & $(\mathrm{T})$ & 1.7 & 1.7 & 1.7 & 1.7 & 2.0 & 1.7 & 2.6 & 1.9 \\
\hline \multirow[t]{2}{*}{ BXO556 } & (O) & R (2.0) & $\mathrm{R}(3.0)$ & $\mathrm{R}(2.5)$ & $\mathrm{R}(1.5)$ & $S(6.0)$ & $\mathrm{S}(6.5)$ & $S(6.5)$ & 4.0 \\
\hline & $(\mathrm{T})$ & 1.4 & 1.7 & 1.6 & 1.2 & 2.4 & 2.5 & 2.5 & 1.9 \\
\hline \multirow{2}{*}{ BXO559 } & (O) & $\mathrm{R}(3.0)$ & $\mathrm{R}(2.5)$ & $\mathrm{R}(2.5)$ & $\mathrm{R}(1.5)$ & S (7.0) & $\mathrm{S}(6.5)$ & S (8.0) & 4.4 \\
\hline & $(\mathrm{T})$ & 1.7 & 1.6 & 1.6 & 1.2 & 2.6 & 2.5 & 2.8 & 2.0 \\
\hline \multirow[t]{2}{*}{ BXO562 } & $(\mathrm{O})$ & $\mathrm{R}(3.0)$ & $\mathrm{R}(3.0)$ & $\mathrm{R}(2.5)$ & $\mathrm{R}(2.0)$ & $S(7.0)$ & S (6.5) & $\mathrm{S}(7.5)$ & 4.5 \\
\hline & $(\mathrm{T})$ & 1.7 & 1.7 & 1.6 & 1.4 & 2.6 & 2.5 & 2.7 & 2.0 \\
\hline \multirow[t]{2}{*}{ BXO563 } & $(\mathrm{O})$ & $\mathrm{R}(3.0)$ & $\mathrm{R}(3.0)$ & $\mathrm{R}(3.5)$ & $\mathrm{R}(2.5)$ & $S(7.0)$ & S (6.0) & $\mathrm{S}(7.5)$ & 4.6 \\
\hline & $(\mathrm{T})$ & 1.7 & 1.7 & 1.9 & 1.6 & 2.6 & 2.4 & 2.7 & 2.1 \\
\hline \multirow[t]{2}{*}{ BXO568 } & (O) & $\mathrm{R}(2.5)$ & $\mathrm{R}(3.0)$ & $\mathrm{R}(3.0)$ & $\mathrm{R}(2.5)$ & $S(6.5)$ & S (5.0) & $S(7.5)$ & 4.3 \\
\hline & $(\mathrm{T})$ & 1.6 & 1.7 & 1.7 & 1.5 & 2.5 & 2.2 & 2.7 & 2.0 \\
\hline \multirow[t]{2}{*}{ BXO571 } & (O) & $\mathrm{R}(3.0)$ & $\mathrm{R}(3.5)$ & $\mathrm{R}(3.5)$ & $\mathrm{R}(2.5)$ & $S(5.5)$ & $\mathrm{S}(5.5)$ & $S(7.5)$ & 4.4 \\
\hline & $(\mathrm{T})$ & 1.7 & 1.9 & 1.9 & 1.6 & 2.3 & 2.3 & 2.7 & 2.0 \\
\hline \multirow[t]{2}{*}{ BXO574 } & $(\mathrm{O})$ & R (3.0) & R (3.0) & R (3.0) & R (3.0) & S (7.0) & S (6.0) & S (6.5) & 4.5 \\
\hline & $(\mathrm{T})$ & 1.7 & 1.7 & 1.7 & 1.7 & 2.6 & 2.4 & 2.5 & 2.0 \\
\hline \multirow[t]{2}{*}{ BXO578 } & (O) & R (3.0) & R (3.0) & $\mathrm{R}(4.0)$ & $\mathrm{R}(2.5)$ & S (6.0) & $\mathrm{S}(5.5)$ & S (7.0) & 4.4 \\
\hline & $(\mathrm{T})$ & 1.7 & 1.7 & 1.9 & 1.5 & 2.4 & 2.3 & 2.6 & 2.0 \\
\hline \multirow[t]{2}{*}{ BXO582 } & (O) & R (3.0) & $\mathrm{R}(2.5)$ & $\mathrm{R}(4.5)$ & $\mathrm{R}(1.5)$ & $\mathrm{S}(5.5)$ & S (5.0) & S (8.0) & 4.3 \\
\hline & $(\mathrm{T})$ & 1.7 & 1.6 & 2.1 & 1.2 & 2.3 & 2.2 & 2.8 & 2.0 \\
\hline \multirow[t]{2}{*}{ BXO586 } & $(\mathrm{O})$ & $\mathrm{R}(3.0)$ & $\mathrm{R}(3.5)$ & $\mathrm{R}(3.0)$ & $\mathrm{R}(1.5)$ & S (5.0) & $\mathrm{S}(6.0)$ & S (7.0) & 4.3 \\
\hline & $(\mathrm{T})$ & 1.7 & 1.9 & 1.7 & 1.2 & 2.2 & 2.4 & 2.6 & 1.9 \\
\hline \multirow{2}{*}{ BXO589 } & (O) & $\mathrm{R}(3.0)$ & $\mathrm{R}(2.5)$ & $\mathrm{R}(3.0)$ & $\mathrm{R}(2.5)$ & $S(6.0)$ & S (6.5) & $\mathrm{S}(8.0)$ & 4.5 \\
\hline & $(\mathrm{T})$ & 1.7 & 1.6 & 1.7 & 1.6 & 2.4 & 2.5 & 2.8 & 2.0 \\
\hline \multirow[t]{2}{*}{ BXO590 } & (O) & R (3.5) & $\mathrm{R}(1.5)$ & $\mathrm{R}(3.5)$ & $\mathrm{R}(1.5)$ & $\mathrm{R}(4.5)$ & $\mathrm{R}(4.0)$ & $S(7.5)$ & 3.5 \\
\hline & $(\mathrm{T})$ & 1.6 & 1.2 & 1.9 & 1.2 & 2.1 & 2.0 & 2.7 & 1.8 \\
\hline \multirow[t]{2}{*}{ BXO454 } & (O) & $\mathrm{R}(3.0)$ & $\mathrm{R}(3.0)$ & $\mathrm{R}(3.5)$ & $\mathrm{R}(3.0)$ & S (6.0) & $\mathrm{S}(6.5)$ & $\mathrm{S}(8.0)$ & 4.7 \\
\hline & $(\mathrm{T})$ & 1.7 & 1.7 & 1.9 & 1.7 & 2.4 & 2.5 & 2.8 & 2.1 \\
\hline \multirow[t]{2}{*}{ BXO471 } & $(\mathrm{O})$ & R (3.5) & R (3.5) & $\mathrm{R}(2.5)$ & $\mathrm{R}(2.0)$ & S (7.0) & $S(6.5)$ & S (7.0) & 4.6 \\
\hline & $(\mathrm{T})$ & 1.9 & 1.9 & 1.6 & 1.4 & 2.6 & 2.5 & 2.6 & 2.1 \\
\hline \multirow[t]{2}{*}{ Mean } & (O) & 2.8 & 3.0 & 3.1 & 2.3 & 6.1 & 5.8 & 7.5 & \\
\hline & $(\mathrm{T})$ & 1.7 & 1.7 & 1.8 & 1.5 & 2.5 & 2.4 & 2.7 & \\
\hline
\end{tabular}

\footnotetext{
a Virulence assays were performed as described in text. Experiments were repeated twice. $\mathrm{R}=$ Resistant; $\mathrm{S}=$ susceptible. Disease scores are in parantheses. Mean and transformed values are presented.

b BXO 454 and 471 belong to pathotype $1 \mathrm{~b}$, a widely distributed lineage of $X$. oryzae pv. oryzae isolated from cultivated rice in India $(12,13,19)$. $(\mathrm{O})=$ Original value; $(\mathrm{T})=$ transformed value $\mathrm{CD}$ at $5 \% \mathrm{~V}=0.09 i=0.14 \mathrm{INT}=0.36 \mathrm{CV} \%=8.83$.

${ }^{c}$ Resistance genes reported in these rice cultivars are $X a-21$ (IRBB21), $x a-5$ and $x a-13$ (BJ1), $x a-5$ and $X a-7$ (DV85), $X a-3$ (CempoSelak), and $X a-4$ (IR20). The resistance genes in IET8585 have not been identified. IET8585 was obtained from the cross IR8/BJ1//IR22/CR98-7216. TN-1 was included as a susceptibility check.
} 
Interact. 5:451-459.

6. International Rice Research Institute. 1980. Page 44 in: Standard Evaluation System for Rice. International Rice Research Institute, Manila, Philippines.

7. Kauffman, H. E., Reddy, A. P. K., Hsieh, S. P. Y., and Merca, S. D. 1973. An improved technique for evaluation of resistance of rice varieties to Xanthomonas oryzae. Plant Dis. Rep. 57:537-541.

8. Leach, J. E., Rhoads, M. L., Vera Cruz, C. M., White, F. W., and Mew, T. W. 1992. Assessment of genetic diversity and population structure of Xanthomonas oryzae pv. oryzae with a repetitive DNA element. Appl. Environ. Microbiol. 54:2188-2195.

9. Leach, J. E., White, F. W., Rhoads, M. L., and Leung, H. 1990. A repetitive DNA sequence differentiates Xanthomonas campestris pv. oryzae from other pathovars of Xanthomonas campestris. Mol. Plant-Microbe Interact. 3:238246.

10. Mew, T. W. 1989. An overview of the world bacterial blight situation. Pages 7-13 in: Proc. Int. Workshop Bacterial Blight Rice. Interna- tional Rice Research Institute, Manila, Philippines.

11. Nelson, R. J., Baraoidan, M. R., Vera Cruz, C. M., Yap, I. V., Leach, J. E., Mew, T. W., and Leung, H. 1994. Relationship between phylogeny and pathotype for the bacterial blight pathogen of rice. Appl. Environ. Microbiol. 60:3275-3283.

12. Reddy, M. T. S., and Reddy, A. P. K. 1989. A new pathotype of Xanthomonas campestris pv. oryzae. Int. Rice Res. Newsl. 14:17-18.

13. Reddy, A. P. K., Srinivasan, T. E., and John, V. T. 1980. Breeding for bacterial leaf blight resistance in rice. Pages 5-13 in: Proc. Natl. Sem. Dis. Resistance Crop Plants. Tamil Nadu Agricultural University, Coimbatore, India.

14. Srivastava, D. N. 1967. Epidemiology of bacterial blight of rice and its control in India. Pages 11-18 in: Proc. Symp. Rice Dis. \& Control Growing Resistant Varieties \& Other Measures. Agriculture, Forestry and Fisheries Research Council, Tokyo, Japan.

15. Swings, J., Mooter, M. V., Vauterin, L., Hoste, B., Gillis, M., Mew, T. W., and Kersters, K. 1990. Reclassification of the causal agents of bacterial blight of rice (Xanthomonas cam- pestris pv. oryzae) and bacterial leaf streak (Xanthomonas campestris pv. oryzicola) of rice as pathovars of Xanthomonas oryzae (ex Ishiyama 1922) sp. nov., nom. rev. Int. J. Syst. Bacteriol. 40:309-311.

16. Tsuchiya, K., Mew, T. W., and Wakimoto, S. 1982. Bacteriological and pathological characteristics of wild types and induced mutants of Xanthomonas campestris pv. oryzae. Phytopathology 72:43-46.

17. Vaughan, D. A. 1994. The Wild Relatives of rice: A Genetic Resources Handbook. International Rice Research Institute, Manila, Philippines. p. 137.

18. Yap, I., and Nelson, R. J. 1996. WinBoot: A program for performing bootstrap analysis of binary data to determine the confidence limits of UPGMA-based dendrograms. IRRI Discussion Pap. Ser. No. 14. International Rice Re search Institute, Manila, Philippines.

19. Yashitola, J., Krishnaveni, D., Reddy, A. P. K., and Sonti, R. V. 1997. Genetic diversity within the population of Xanthomonas oryzae pv. oryzae in India. Phytopathology 87:760765. 